\title{
Susceptibility of apple cultivars to bark canker diseases
}

\author{
ZBIGNIEW BORECKI ${ }^{1}$ and ALOJZY CZYNCZYK ${ }^{2}$
} ${ }^{1}$ Department of Plant Pathology, Warsaw Agricultural University, ul. Nowoursynowska 166,
02-766 Warszawa, Poland

${ }^{2}$ Research Institute of Pomology and Floriculture, ul. Pomologiczna 18, 96-100 Skierniewice, Poland

$\langle$ Received: November 15,1983$\rangle$

\begin{abstract}
The susceptibility of 26 apple cultivars to four bark parasites: Nectria galligena, Pezicula malicorticis, Stereum purpureum and Phytophthora cactorum was investigated. A close correlation was found between indices of susceptibility to the fungi $N$.galligena, P. malicorticis and $S$. purpureum and no correlation between the indices of susceptibility to $P$. cactorum and the three remaining pathogens. Five groups of susceptibility to the complex of bark canker fungi were distinguished, oomprising three or four species of fungi. Highly susceptible cultivars: 'Delikates', 'Melrose', 'Spartan', 'Prima' and 'Slava Pobeditelam'. Rather susceptible cultivars: 'Starkrimson', 'Hibernal', 'Florina', 'Priscilla', 'Priam', 'Macfree' and 'NY 55-158-2'. Moderately susceptible cultivars: 'Macoun', 'Liberty', 'NY 55-140-9', 'Vista Bella', 'Jerseymac' and 'Sampion'. Little susceptible cultivars: 'Discovery', 'Empire', 'Fantazja' and 'Primula'. But slightly susceptible cultivars: 'Golden Delicious', 'Idared' and 'NY 58-533-1'.
\end{abstract}

\section{INTRODUCTION}

Bark canker fungi of fruit trees are very noxious pathogens and difficult to control on apple trees. The diseases caused by them are colloquially referred to as bark canker. In Poland three diseases of this group are common: European canker 〈Nectria galligena Bres. $\rangle$, perennial bark canker $\langle$ Pezicula malicorticis $\langle$ Jack. $\rangle$ Nannf. $\rangle$ and silver leaf $\langle$ Stereum purpureum $\langle$ Pers. ex Fr. $\rangle \mathrm{Fr}\rangle$. Moreover locally collar rot of apple $\langle$ P hytophthora cactorum $\langle$ Lebert. et Cohn. $\rangle$ Schroet. $\rangle$ is found. All these diseases are known in most regions where apples are cultivated in Europe and North America $\angle B$ i e l e $n$ i n and B ore c ki, 1970; B o r e c i and P u chała, 1976; D y e, 1972; J e ff e r s et al., 1982; M a j z o u b, 1978>.

For protection of apple trees from bark canker fungi mainly agrotechnical and chemical methods are used, and lately attempts have been undertaken to exploit biological methods and the resistance of apple cultivars. 
Investigations on the susceptibility of apple cultivars to canker are mainly conducted in Germany and Poland. $\mathrm{K} \mathrm{rah} \mathrm{mer}$ and $\mathrm{Schmidle}$ $\langle 1979\rangle$ and $\mathrm{S}$ i $1 \mathrm{~b}$ e r e i s e $\mathrm{n}\langle 1978\rangle$ noted a high susceptibility of the following cultivars to Nectria galligena: 'Cox Orange', 'Idared', 'Orangenburg', 'Maigold', 'Alkmene', 'McIntosh', 'Rogers' and 'Gloster'. Much more resistant was the cultivar 'Maunzen'. Recently K r ü.g e r 〈1982〉 studied the susceptibility of apple cultivars to canker and distinguished five groups of apple susceptibility to this disease. She considered as highly susceptible the cultivars: 'Jonadel', 'Ontario', 'Priscilla' and 'Spartan', as moderately to highly susceptible: 'Cox Orange' and 'Macoun'. As moderately susceptible: 'Golden Delicious', 'Idared' and 'Antonowka', as moderately or little susceptible 'Jonagold'. This author believed the cultivar 'Schöner aus Nordhausen' to be the only resistant variety.

In Poland Borecki with a group of coauthors mainly studied the American apple trees resistant to Venturia inaequalis $\mathrm{Cke}\langle$ Winter $\rangle$ and found that most of these varieties are susceptible to bark canker fungi $\langle\mathrm{B}$ o $\mathrm{r}$ e c k i et al., 1982 $\rangle$. Most sensitive proved to be: 'Priscilla' and 'Macfree', whereas the cultivar 'NY 58-553-1' was relatively resistant. It is a difficult task to obtain apple trees with complex resistance to several of the most dangerous diseases, but it is a trait postulated more and more frequently by breeders and pomologists $\langle\mathrm{A} 1 \mathrm{~d}$ w i n c k l e and $\mathrm{L} \mathrm{a} \mathrm{m} \mathrm{b,} \mathrm{1974,} \mathrm{1981 \rangle .} \mathrm{The} \mathrm{susceptibility} \mathrm{of} \mathrm{apple} \mathrm{trees} \mathrm{to}$ parasites of the bark parenchyma depends largely not only on the biochemical properties, but also on predisposing inorganic factors, mainly frost damage and water deficit in the tissues as well as viral infection increasing susceptibility of apple trees to canker $\langle\mathrm{C}$ a m e r o $\mathrm{n}, 1977\rangle$.

\section{MATERIAL AND METHODS}

The susceptibility to bark canker fungi was evaluated in 26 apple cultivars including ten resistant to apple scab. Four varieties as control combinations served as standards for the earlier established high susceptibility to four parasitic fungi: 'Spartan' to Nectria galligena, 'McIntosh' to Pezicula malicorticis 'Melrose' to Stereum purpureum and 'Hibernal' to Phytophthora cactorum. The remaining apple trees belonged to the most important cultivars at present grown in Poland or very promising under the conditions of this country $\langle$ Table 1$\rangle$.

The experiments were performed under field conditions in the years 1980-1982 on two-year-old apple trees in two experimental stations of the Institute of Pomology and Floriculture in Skierniewice and Dąbrowice situated close to each other. Each of the 26 cultivars was represented in each station by 40 specimens planted in the autumn of 1980 at a $0.5 \times 2.5 \mathrm{~m}$ spacing. In the autumn 1981 ten trees of each variety were infected with the fungi Nectria galligena, Pezicula malicorticis and Stereum purpureum, and the remaining ten in spring 1982 with the fungus Phytopthora cactorum. The trees were inoculated in the period of highest susceptibility of the apple trees to the fungi. For inoculation a small strip 
Table 1

Short description of tested apple cultivars*

\begin{tabular}{|c|c|c|c|c|}
\hline \multirow[b]{2}{*}{ Cultivar } & \multirow[b]{2}{*}{ Originated in: } & \multirow[b]{2}{*}{$\begin{array}{l}\text { Ripening } \\
\text { season }\end{array}$} & \multicolumn{2}{|c|}{ Susceptibility to: } \\
\hline & & & apple scab & $\begin{array}{c}\text { apple } \\
\text { powdery } \\
\text { mildew }\end{array}$ \\
\hline 'Šampion' & Czechoslovakia & autumn & 3 & 3 \\
\hline 'Delikates' & Poland & autumn & 4 & 3 \\
\hline 'Discovery' & England & autumn & 2 & 2 \\
\hline "Empire" & USA & winter & 3 & $\mathbf{3}$ \\
\hline 'Fantazja' & Poland & late autumn & 4 & 3 \\
\hline 'Florina' & France & winter & $\mathbf{1}$ & 2 \\
\hline 'Golden Delicious' & USA & winter & 2 & 2 \\
\hline 'Hibernal' & Soviet Union & late autumn & 2 & 2 \\
\hline 'Idared' & USA & winter & 3 & 5 \\
\hline 'Jerseymac' & USA & summer & 5 & 3 \\
\hline 'Liberty' & USA & winter & 1 & 2 \\
\hline 'Macfree' & Canada & winter & 1 & $\mathbf{5}$ \\
\hline 'Macoun' & USA & winter & 4 & 3 \\
\hline 'McIntosh' & Canada & winter & 5 & 3 \\
\hline 'Melrose' & USA & winter & 2 & 3 \\
\hline 'NY 55-140-9' & USA & autumn & 1 & 2 \\
\hline 'NY 55-158-2' & USA & winter & $\mathbf{1}$ & 3 \\
\hline 'NY 58-553-1' & USA & winter & 1 & 3 \\
\hline 'Priam' & France & winter & 1 & 2 \\
\hline 'Prima' & USA & winter & 1 & 2 \\
\hline 'Primula' & USA & summer & 1 & 2 \\
\hline 'Priscilla' & USA & winter & $\mathbf{1}$ & $\mathbf{5}$ \\
\hline 'Slava Pobeditelam' & Soviet Union & autumn & 5 & 3 \\
\hline 'Spartan' · & Canada & winter & 3 & 2 \\
\hline 'Starkrimson' & USA & winter & 4 & 2 \\
\hline 'Vista Bella' & USA & summer & $\mathbf{5}$ & 3 \\
\hline
\end{tabular}

* Susceptibility to apple scab and apple powdery mildew according to five degree scale: 1 - resistant, 2 - little susceptible, 3 - moderately susceptible 4 - rather susceptible, 5 - highly susceptible.

of bark was removed from the trunk $25 \mathrm{~cm}$ above the soil level. A piece of fungal mycelium on agar medium $\langle 4 \times 12 \mathrm{~mm}\rangle$ was placed on the cut surface and the inoculum was covered with polyethylene tape. Fungal cultures were prepared for infection on PDA Difco medium. After three weeks the foil was removed from the wound. Lesions developing after spring infection with $P$. cactorum were measured after a lapse of four months and the lesions after autumn infection with the remaining fungi after six months.

The results of experiments were elaborated statistically by the method of analysis of variance and the significance of the differences was evaluated by Duncan's test at the level $L=0.05$. On account of the wide differences between the cultivars in the size of the lesions, the entire statistical analysis was performed 
on values transformed according to the logarithmic transformation of $x=\log$ $\langle z+1\rangle$ type where $z$ denotes length of lesion. Moreover the value of the coefficient of linear correlation $r$ was calculated for the dependence between the length of lesions caused by different bark canker fungi.

\section{RESULTS}

Susceptibility of apple cultivars to European canker 〈Nectria galligena〉

The tested cultivars greatly differed in their susceptibility to canker $\langle$ Table 2$\rangle$. Evidence of these differences are as many as 11 indexes of difference significance denoted in Table 2 by symbols from $a$ to $k$.

Table 2

Susceptibility of apple cultivars to european canker (Nectria galligena)*

\begin{tabular}{|c|c|c|c|c|}
\hline \multirow{2}{*}{ Cultivar } & \multicolumn{3}{|c|}{ Mean length of lesion, $\mathrm{mm}$} & \multirow{2}{*}{$\begin{array}{l}\text { Susceptibility } \\
\text { group }\end{array}$} \\
\hline & in Dąbrowice & in Skierniewice & mean & \\
\hline $\begin{array}{l}\text { 'Spartan' } \\
\text { 'Delikates' } \\
\text { 'Starkrimson' } \\
\text { 'Jerseymac' }\end{array}$ & $\begin{array}{ll}167.5 & \mathrm{k} \\
164.7 & \mathrm{k} \\
128.7 \mathrm{jk} \\
140.4 \mathrm{jk}\end{array}$ & $\begin{array}{ll}242.6 & \mathrm{l} \\
200.0 & \mathrm{kl} \\
240.7 & \mathrm{l} \\
187.0 \mathrm{jkl}\end{array}$ & $\begin{array}{l}201.6 \mathrm{k} \\
181.5 \mathrm{k} \\
176.0 \mathrm{jk} \\
162.1 \mathrm{j}\end{array}$ & $\begin{array}{l}\text { highly } \\
\text { susceptible }\end{array}$ \\
\hline $\begin{array}{l}\text { 'NY 55-158-2' } \\
\text { 'Melrose' } \\
\text { 'Vista Bella' } \\
\text { 'McIntosh' }\end{array}$ & $\begin{array}{rl}92,8 & \mathrm{hi} \\
112.9 \mathrm{ij} \\
112,3 \mathrm{ij} \\
96.4 \mathrm{hi}\end{array}$ & $\begin{array}{l}180.6 \text { ijk } \\
143.4 \text { ghij } \\
140.0 \text { ghi } \\
151.7 \text { hijk }\end{array}$ & $\begin{array}{l}129.5 \mathrm{i} \\
127.2 \mathrm{i} \\
125.4 \mathrm{i} \\
120.9 \mathrm{i}\end{array}$ & $\begin{array}{l}\text { rather } \\
\text { susceptible }\end{array}$ \\
\hline $\begin{array}{l}\text { 'Prima' } \\
\text { 'Šampion' } \\
\text { 'Macfree' } \\
\text { 'Slava Pobeditelam' } \\
\text { 'Priscilla' } \\
\text { 'Liberty' } \\
\text { 'Macoun' }\end{array}$ & $\begin{array}{l}91.2 \mathrm{hi} \\
81.2 \mathrm{gh} \\
96.0 \mathrm{hi} \\
71.4 \mathrm{gh} \\
76.7 \mathrm{gh} \\
73.2 \mathrm{gh} \\
63.8 \mathrm{fg}\end{array}$ & $\begin{array}{r}108.4 \text { efg } \\
120.4 \text { fgh } \\
99.8 \text { def } \\
120.3 \text { fgh } \\
112.1 \text { efg } \\
98.5 \text { def } \\
94.5 \text { def }\end{array}$ & $\begin{array}{l}99.4 \mathrm{~h} \\
98.8 \mathrm{~h} \\
97.9 \mathrm{~h} \\
92.7 \mathrm{gh} \\
92.7 \mathrm{gh} \\
84.9 \mathrm{fgh} \\
77.6 \mathrm{efg}\end{array}$ & $\begin{array}{l}\text { moderately } \\
\text { susceptible }\end{array}$ \\
\hline $\begin{array}{l}\text { 'NY 55-140-9' } \\
\text { 'Priam' } \\
\text { 'Empire' } \\
\text { 'Florina' } \\
\text { 'Hibernal' } \\
\text { 'Primula' }\end{array}$ & $\begin{array}{l}62.3 \text { efg } \\
47.7 \text { de } \\
38.2 \text { cd } \\
38.1 \text { cd } \\
49.0 \text { def } \\
34.2 \text { bc }\end{array}$ & $\begin{array}{l}79.2 \mathrm{~d} \\
86.0 \mathrm{de} \\
90.5 \mathrm{def} \\
49.0 \mathrm{c} \\
34.5 \mathrm{~b} \\
41.2 \mathrm{bc}\end{array}$ & $\begin{array}{l}70.3 \text { def } \\
64.1 \text { de } \\
58.8 \mathrm{~d} \\
43.2 \mathrm{c} \\
41.1 \mathrm{c} \\
37.5 \mathrm{c}\end{array}$ & $\begin{array}{l}\text { little } \\
\text { susceptible }\end{array}$ \\
\hline $\begin{array}{l}\text { 'Fantazja' } \\
\text { 'Discovery' } \\
\text { 'NY 58-553-1' } \\
\text { 'Golden Delicious' } \\
\text { 'Idared' }\end{array}$ & 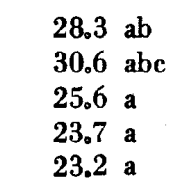 & $\begin{array}{l}23.0 \text { a } \\
24.7 \text { a } \\
20.5 \text { a } \\
21.4 \text { a } \\
19.5 \text { a }\end{array}$ & $\begin{array}{ll}30.5 & b \\
27.5 & \text { b } \\
22.9 & \text { a } \\
22.5 & \text { a } \\
21.3 & \text { a }\end{array}$ & $\begin{array}{l}\text { very little } \\
\text { susceptible }\end{array}$ \\
\hline
\end{tabular}

*Means within a vertical column followed by the same letters are not significantly different at $5 \%$ level of probability. 
On the basis of these results five groups of susceptibility of the cultivars can be distinguished. To the very sensitive ones on which the length of lesions exceeded $150 \mathrm{~mm}$ belong: 'Spartan', 'Delikates', 'Starkrimson' and 'Jerseymac'. The second rather susceptible group consisted of: 'NY 55-158-2', 'Melrose', 'Vista Bella' and 'McIntosh'. The third group of moderately susceptible cultivars was the largest and showed the greatest differences. Here belonged 'Prima', 'Sampion', 'Macfree', 'Slava Pobeditelam', 'Priscilla', 'Liberty', 'Macoun', 'NY 55-140-9', 'Priam' and 'Empire'. Little susceptible were: 'Florina', 'Hibernal', 'Primula' and 'Fantazja', and very little susceptible proved: 'Discovery', 'NY 58-553-1', 'Golden Delicious' and 'Idared'. This classification into five groups is conventional and approximative, but it helps in orientational comparison of susceptibility. An accurate evaluation of the reaction of cultivars to artificial infection should be based on the significance indexes established by analysis of variance $\langle$ Table 2$\rangle$.

Ta ble 3

Susceptibility of apple cultivars to apple perennial canker (Pezicula malicorticis)*

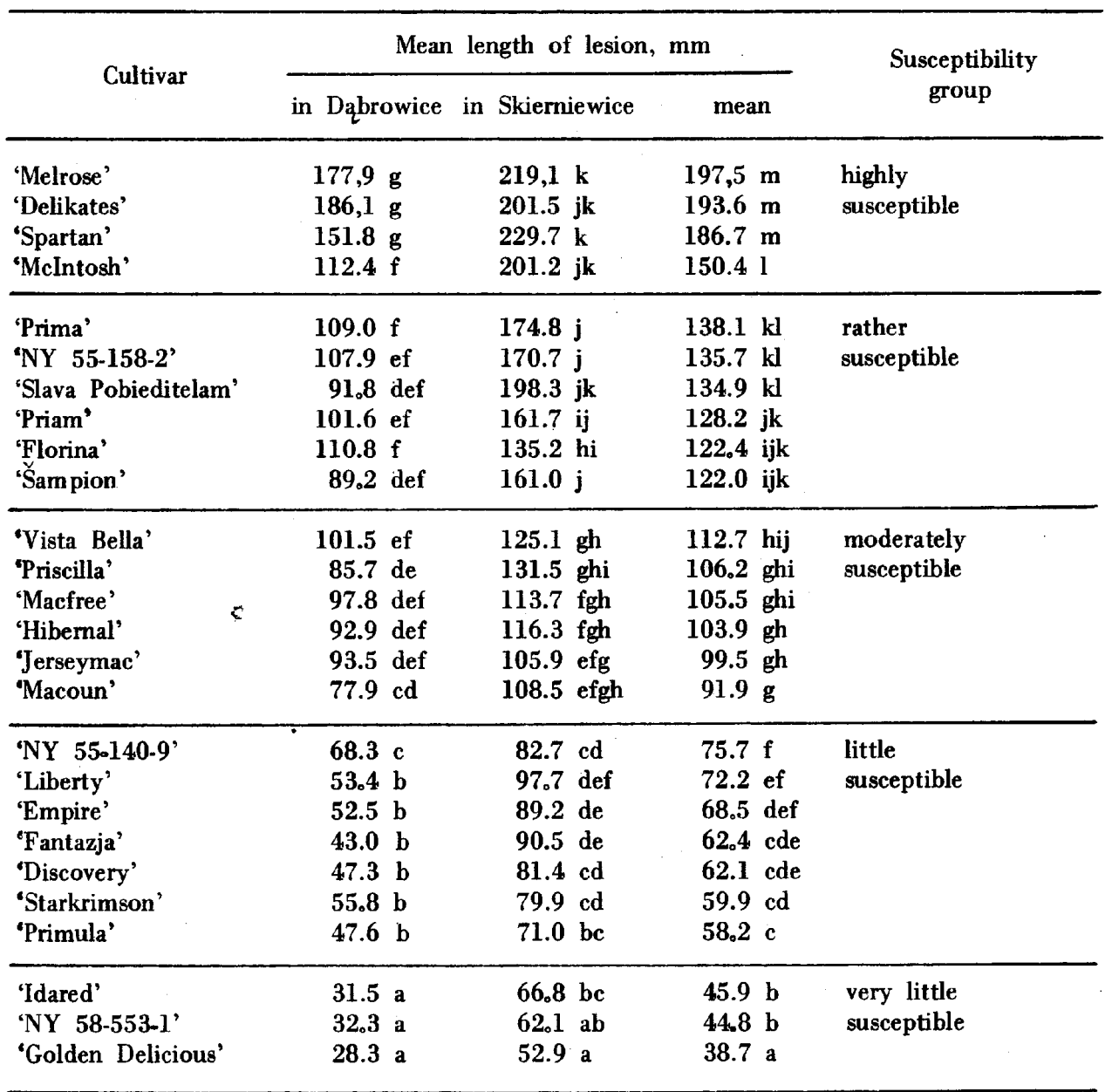




\section{Table 4}

Values of coefficient of linear correlation $r$ for dependence between length of lesions caused by different canker fungi

\begin{tabular}{|c|c|c|c|c|c|c|}
\hline & \multirow{2}{*}{\multicolumn{2}{|c|}{ Canker fungi }} & \multicolumn{4}{|c|}{ Value of correlation coefficient } \\
\hline & & & in & Dąbrowice in & Skiemiewice & mean \\
\hline $\begin{array}{l}\text { Nectria } \\
\text { galligena }\end{array}$ & $x$ & $\begin{array}{l}\text { Pezicula } \\
\text { malicorticis }\end{array}$ & & $0.768^{* *}$ & $0.705^{* *}$ & $0.750 * *$ \\
\hline $\begin{array}{l}\text { Nectria } \\
\text { galligena }\end{array}$ & $x$ & $\begin{array}{l}\text { Stereum } \\
\text { purpureum }\end{array}$ & & $0.502^{* *}$ & $0.616^{* *}$ & $0.621 * *$ \\
\hline $\begin{array}{l}\text { Nectria } \\
\text { galligena }\end{array}$ & $x$ & $\begin{array}{l}\text { Phytophthora } \\
\text { cactorum }\end{array}$ & & 0.176 & 0.006 & -0.036 \\
\hline $\begin{array}{l}\text { Pezicula } \\
\text { malicorticis }\end{array}$ & $x$ & $\begin{array}{l}\text { Stereum } \\
\text { purpureum }\end{array}$ & & $0.615^{* *}$ & $0.804^{* *}$ & $0.768^{* * *}$ \\
\hline $\begin{array}{l}\text { Pezicula } \\
\text { malicorticis }\end{array}$ & $x$ & $\begin{array}{l}\text { Phytophthora } \\
\text { cactorum }\end{array}$ & & $0.492^{\text {** }}$ & $0.385^{*}$ & $0.377^{\circ}$ \\
\hline $\begin{array}{l}\text { Stereum } \\
\text { purpureum }\end{array}$ & $x$ & $\begin{array}{l}\text { Phytophthor } \\
\text { cactorum }\end{array}$ & & $0.351^{\circ}$ & $0.356^{\circ}$ & 0.259 \\
\hline
\end{tabular}

$=0.3233$.

Susceptibility of apple cultivars to perennial canker 〈Pezicula malicorticis〉

Similarly as in the part of the experiment dealing with bark canker, wide differences were found in the size of the lesion on various apple cultivars <Table $3\rangle$. The highest mean values describing the lesion size were found on trees of the cultivar 'Melrose', and the smallest on 'Golden Delicious'. Part of the same cultivars which were classified to the particular groups according to susceptibility to canker can be classified to the groups of susceptibility corresponding to the previously adopted classification: highly susceptible, rather susceptible, moderately susceptible, little susceptible, very little susceptible. A similar susceptibility of apple trees to both diseases is indicated by the relatively high coefficient of linear correlation amounting to $0.750\langle$ Table 4$\rangle$. Among the most susceptible cultivars we find: 'Spartan' and 'Delikates', and in the least susceptible group 'Golden Delicious', 'Idared' and 'NY 58-553-1'.

\section{Susceptibility of apple cultivars to silver leaf $\langle$ Stereum purpureum $\rangle$}

The susceptibility of apple cultivars to the polyphagous fungus Stereum purpureum $\langle$ Table 5> showed much smaller differences than that towards bark canker and perennial canker. The differences in the extent of lesions varied within 


\section{Table 5}

Susceptibility of apple cultivars to silver leaf (Stereum purpureum)

\begin{tabular}{|c|c|c|c|c|}
\hline \multirow{2}{*}{ Cultivar } & \multicolumn{3}{|c|}{ Mean length of lesion, $\mathrm{mm}$} & \multirow{2}{*}{$\begin{array}{l}\text { Susceptibility } \\
\text { group }\end{array}$} \\
\hline & in Dąbrowice & in Skierniewice & mean & \\
\hline $\begin{array}{l}\text { 'Melrose' } \\
\text { 'Slava Pobeditelam' } \\
\text { 'Florina' } \\
\text { 'Delikates' } \\
\text { 'Prima' }\end{array}$ & $\begin{array}{ll}91.4 & 1 \\
88.3 & \mathbf{l} \\
78.7 & \mathbf{k l} \\
71.0 & \mathbf{j j k l} \\
73.0 & \mathbf{j k l}\end{array}$ & $\begin{array}{rl}110.4 & 1 \\
110.9 & 1 \\
102.2 & 1 \\
101.8 & 1 \\
89.5 & \mathrm{kl}\end{array}$ & $\begin{array}{l}100.4 \mathrm{j} \\
99.0 \mathrm{j} \\
89.7 \mathrm{ij} \\
85.0 \mathrm{hij} \\
80.9 \mathrm{ghi}\end{array}$ & $\begin{array}{l}\text { highly } \\
\text { susceptible }\end{array}$ \\
\hline $\begin{array}{l}\text { 'Priscilla' } \\
\text { 'McIntosh' } \\
\text { 'Macfree' }\end{array}$ & $\begin{array}{l}73.3 \mathrm{jkl} \\
62.9 \mathrm{hijk} \\
60.3 \text { ghij }\end{array}$ & $\begin{array}{l}73.5 \mathrm{ijk} \\
77.6 \mathrm{jk} \\
70.1 \mathrm{hijk}\end{array}$ & $\begin{array}{l}73.4 \mathrm{fgh} \\
69.8 \mathrm{fg} \\
65.0 \mathrm{f}\end{array}$ & $\begin{array}{l}\text { rather } \\
\text { susceptible }\end{array}$ \\
\hline $\begin{array}{l}\text { 'Spartan' } \\
\text { 'NY 55-158-2' } \\
\text { 'Empire' } \\
\text { 'Priam' } \\
\text { 'Fantazja' } \\
\text { 'Macoun' } \\
\text { 'Starkrimson' }\end{array}$ & $\begin{array}{l}45.9 \text { efg } \\
52.0 \text { efgh } \\
54.8 \text { efgh } \\
55.3 \text { efghi } \\
46.6 \text { efg } \\
46.2 \text { ef } \\
58.0 \text { fghij }\end{array}$ & $\begin{array}{l}63.0 \text { ghij } \\
56.8 \text { efgh } \\
45.8 \text { cdef } \\
44.6 \text { cde } \\
51.2 \text { defg } \\
51.1 \text { defg } \\
39.0 \text { bc }\end{array}$ & $\begin{array}{l}54.3 \mathrm{e} \\
54.3 \mathrm{e} \\
50.1 \mathrm{e} \\
49.7 \mathrm{e} \\
48.9 \mathrm{de} \\
48.6 \mathrm{de} \\
47.6 \mathrm{de}\end{array}$ & $\begin{array}{l}\text { moderately } \\
\text { susceptible }\end{array}$ \\
\hline $\begin{array}{l}\text { 'Jerseymac' } \\
\text { 'Sampion' } \\
\text { 'Liberty' } \\
\text { 'Primula' } \\
\text { 'Vista Bella' } \\
\text { 'Hibernal' } \\
\text { 'NY 55-140-9' }\end{array}$ & $\begin{array}{l}29.3 \text { bc } \\
42.7 \text { de } \\
45.3 \text { ef } \\
32.8 \text { c } \\
25.2 \text { ab } \\
20.9 \text { a } \\
35.4 \text { cd }\end{array}$ & $\begin{array}{l}58.7 \text { fghi } \\
37.2 \text { bc } \\
34.4 \text { b } \\
32.9 \text { b } \\
35.9 \text { bc } \\
41.4 \text { bcd } \\
22.1 \text { a }\end{array}$ & 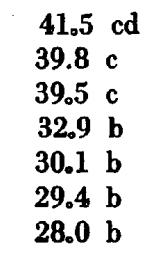 & $\begin{array}{l}\text { little } \\
\text { susceptible }\end{array}$ \\
\hline $\begin{array}{l}\text { 'Golden Delicious' } \\
\text { 'NY 58-553-1' } \\
\text { 'Idared' } \\
\text { 'Discovery' }\end{array}$ & $\begin{array}{l}21.2 \mathrm{a} \\
22.4 \mathrm{a} \\
19.8 \mathrm{a} \\
20.2 \mathrm{a}\end{array}$ & $\begin{array}{l}22.3 \mathrm{a} \\
20.2 \mathrm{a} \\
20.7 \mathrm{a} \\
19.7 \mathrm{a}\end{array}$ & $\begin{array}{l}21.8 \text { a } \\
21.3 \text { a } \\
20.2 \text { a } \\
20.0 \text { a }\end{array}$ & $\begin{array}{l}\text { very little } \\
\text { susceptible }\end{array}$ \\
\hline
\end{tabular}

Explanations of symbols as in Table 2.

the limits of $20.0 \mathrm{~mm}$ on the apple tree 'Discovery' to $100.0 \mathrm{~mm}$ on 'Melrose'. On the leaves of most of the infected trees, notwithstanding the size of the bark lesions, symptoms of silver leaf appeared. They were most frequently observed on trees of the varieties 'Spartan', 'Slava Pobeditelam', 'Florina' and 'Prima', whereas they did not appear at all on the cultivars 'Idared', 'Macoun', 'Discovery', 'NY 58-533-1', 'Hibernal' and 'Jerseymac'.

To the group of apple trees most susceptible to Stereum purpureum belong: 'Melrose', 'Slava Pobeditelam', 'Florina', 'Delikates' and 'Prima'. Least susceptible were the cultivars: 'Discovery', 'Idared', 'Golden Delicious', 'NY 58-553-1' and 'Hibernal'. 
Susceptibility of apple cultivars to collar rot $\langle P$ hytophthora cactorum $\rangle$

The range of differences in the size of lesions is similar as in the trees infected with Stereum purpureum, whereas the reaction of the particular cultivars to infection differed widely from that to the three remaining pathogens $\langle$ Table 6 $\rangle$. Among the most susceptible cultivars are: 'Hibernal', 'Florina', 'Discovery' and 'Delikates', and the least sensitive ones: 'Idared', 'Golden Delicious', 'Jerseymac' and 'NY 58-553-1'. In the part of the experiment concerning susceptibility of apple trees to the fungus $P$. cactorum the greatest dispersion of results for the same cultivars at both experimental stations was noted. As example may be quoted the indexes of susceptibility of the cultivar 'Hibernal'. On this tree the mean size of

$$
\text { Table } 6
$$

Susceptibility of apple cultivars to collar rot (Phytophthora cactorum)

\begin{tabular}{|c|c|c|c|c|}
\hline \multirow{2}{*}{ Cultivar } & \multicolumn{3}{|c|}{ Mean length of lesion, $\mathrm{mm}$} & \multirow{2}{*}{$\begin{array}{l}\text { Susceptibility } \\
\text { group }\end{array}$} \\
\hline & in Dąbrowice & in Skierniewice & mean & \\
\hline $\begin{array}{l}\text { 'Hibernal' } \\
\text { 'Florina' } \\
\text { 'Discovery' }\end{array}$ & $\begin{array}{l}60.3 \mathrm{j} \\
34.7 \mathrm{fgh} \\
43.7 \mathrm{hi}\end{array}$ & $\begin{array}{l}251.1 \mathrm{k} \\
192.8 \mathrm{j} \\
133.4 \mathrm{i}\end{array}$ & $\begin{array}{r}123.0 \mathrm{in} \\
81.8 \mathrm{~m} \\
76.3 \mathrm{~lm}\end{array}$ & $\begin{array}{l}\text { highly } \\
\text { susceptible }\end{array}$ \\
\hline $\begin{array}{l}\text { 'Delikates' } \\
\text { 'Priscilla' }\end{array}$ & $\begin{array}{l}55.8 \mathrm{j} \\
46.0 \mathrm{ij}\end{array}$ & $\begin{array}{l}80.4 \mathrm{~g} \\
88.3 \mathrm{gh}\end{array}$ & $\begin{array}{l}67.0 \mathrm{kl} \\
63.7 \mathrm{jk}\end{array}$ & $\begin{array}{l}\text { rather } \\
\text { susceptible }\end{array}$ \\
\hline $\begin{array}{l}\text { 'Priam' } \\
\text { 'Melrose' } \\
\text { 'Prima' } \\
\text { 'Macfree' } \\
\text { 'Slava Pobeditelam' } \\
\text { 'Liberty' } \\
\text { 'NY 55-140-9' } \\
\text { 'McIntosh' }\end{array}$ & $\begin{array}{l}37.8 \text { de } \\
38.1 \text { ghi } \\
35.6 \text { fgh } \\
35.4 \text { fgh } \\
34.5 \text { fgh } \\
29.4 \text { def } \\
20.2 \text { abc } \\
24.7 \text { cd }\end{array}$ & $\begin{array}{r}92.7 \mathrm{gh} \\
90.6 \mathrm{gh} \\
94.9 \mathrm{gh} \\
90.4 \mathrm{gh} \\
82.5 \mathrm{~g} \\
81.9 \mathrm{~g} \\
108.9 \mathrm{hi} \\
76.0 \mathrm{~g}\end{array}$ & $\begin{array}{l}59.2 \text { ijk } \\
58.7 \text { ijk } \\
58.1 \text { ijk } \\
56.6 \text { hij } \\
53.3 \text { ghi } \\
49.1 \text { fgh } \\
46.9 \text { fg } \\
4.3 .4 \text { ef }\end{array}$ & $\begin{array}{l}\text { moderately } \\
\text { susceptible }\end{array}$ \\
\hline $\begin{array}{l}\text { 'Sampion' } \\
\text { 'Fantazja' } \\
\text { 'NY 55-158-2' } \\
\text { 'Empire' } \\
\text { 'Spartan' } \\
\text { 'Macoun' } \\
\text { 'Vista Bella' } \\
\text { 'Primula' }\end{array}$ & $\begin{array}{l}27.2 \text { de } \\
26.0 \text { d } \\
38.2 \text { ghi } \\
39.3 \text { ghi } \\
29.2 \text { def } \\
20.3 \text { abc } \\
27.3 \text { de } \\
33.2 \text { efg }\end{array}$ & $\begin{array}{l}57.9 \text { f } \\
57.8 \text { f } \\
38.3 \text { d } \\
28.2 \text { bc } \\
35.3 \text { cd } \\
49.1 \text { ef } \\
34.0 \text { cd } \\
28.0 \text { bc }\end{array}$ & $\begin{array}{l}39.7 \text { c } \\
38.8 \text { de } \\
38.3 \text { de } \\
33.3 \text { cd } \\
32.1 \text { bc } \\
31.6 \text { bc } \\
30.5 \text { bc } \\
30.5 \text { bc }\end{array}$ & $\begin{array}{l}\text { little } \\
\text { susceptible }\end{array}$ \\
\hline $\begin{array}{l}\text { 'NY 58-553-1' } \\
\text { 'Jerseymac' } \\
\text { 'Golden Delicious' } \\
\text { 'Tdared' }\end{array}$ & $\begin{array}{l}23.4 \mathrm{bcd} \\
19.2 \mathrm{ab} \\
18.1 \mathrm{a} \\
18.4 \mathrm{a}\end{array}$ & $\begin{array}{l}33.0 \text { cd } \\
25.3 \text { ab } \\
22.3 \text { a } \\
21.2 \text { a }\end{array}$ & $\begin{array}{ll}27.8 & \text { b } \\
22.1 & \text { a } \\
20.1 & \text { a } \\
19.7 & \text { a }\end{array}$ & $\begin{array}{l}\text { very little } \\
\text { susceptible }\end{array}$ \\
\hline
\end{tabular}

Explanations of symbols as in Table 2. 
lesions in Skierniewice was $60.3 \mathrm{~mm}$, while in Dąbrowice as much as $251.1 \mathrm{~mm}$. Similar differences were observed on the apple trees: 'Florina', 'Discovery', 'NY 55-140-9', 'Liberty', 'Priam', 'Prima' and 'Slava Pobeditelam'.

\section{DISCUSSION AND CONCLUSIONS}

The here reported experiments are a successive third series in the research on susceptibility of apple cultivars to bark canker fungi, started in 1976. In the first series only six of the cultivars were tested $\langle\mathrm{B}$ o r e c k i et al., 1978 $\rangle$ and in the second twelve cultivars $\langle\mathrm{B}$ o r e c k i et al., 1982〉.

The greatest difficulty in evaluation of the susceptibility of apple, trees to bark canker was the strong dependence of the results of artificial infection on atmospheric conditions, particularly temperature in the first weeks after tree infection. These conditions were very favourable in the autumn of 1981 and spring 1982 for all pathogens. This may explain the rapid development of lesions and the wide differences in their dimensions on the tested varieties. A very important factor influencing the results of the experiments was the general good condition of the trees, excluding the action of additional predisposing factors such as water deficit in the tissues, weakened growth owing to intensive development of leaf parasites and frost damage. Important was also the high virulence of the pathogens used for artificial infection. This condition required continuous supplementation of the collection of fungi, search for the most pathogenic forms and the use for infection of relatively young malt agar cultures of the fungi. These factors were particularly important as regards the fungi Phytophthora cactorum and Pezicula malicorticis.

The experiments did not confirm the opinion of $\mathrm{S}$ i $1 \mathrm{~b}$ e r e i s e $\mathrm{n}\langle 1978$ > as to the high susceptibility of the cultivar 'Idared' to European canker. The evaluation of the cultivar 'McIntosh' was, however similar. The opinion of K r ü g e r 〈1982〉 on the high susceptibility of the cultivar 'Spartan' to this disease was confirmed. On the other hand, the apple trees 'Idared' and 'Golden Delicious' considered by this author as moderately susceptible, proved in the present experiment very little sensitive. The cultivar 'Macoun' was considered by this author, in agreement with the present results, as moderately resistant.

In the group of ten trees resistant to apple scab only 'NY 58-553-1' exhibited a very low susceptibility to all the parasitic fungi tested. Most of the remaining cultivars in this series belonged to moderately or highly susceptible ones. Particularly sensitive to bark canker proved to be 'Florina' and 'Prima' to silver leaf, and 'Florina' to collar rot.

The attempt to consider complex resistance or susceptibility of apples trees to the four tested pathogens is difficult owing to the different values of the correlation coefficient for the relation between the indices of susceptibility to various diseases $\langle$ Table 6$\rangle$. These coefficients are high for the fungi: Nectria galligena and Pezicula malicorticis $\langle\mathrm{r}=0.750\rangle$, Pezicula malicorticis and 
Stereum purpurem $\langle\mathrm{r}=0.768\rangle$ and Nectria galligena and Stereum purpureum $\langle\mathrm{r}=0.621\rangle$. No strict correlation was found in the combination: Nectria galligena $\times$ Phytophthora cactorum $\langle-0.036\rangle$ and Stereum purpureum $\times$ Phytophthora cactorum $\langle 0.259\rangle$. A relatively low value of the correlation coefficient was noted between the indices of susceptibility to the fungi Pezicula malicorticis and Phytophthora cactorum $\langle 0.377\rangle$.

The relations between susceptibility of the apple cultivars to the four parasitic fungi are very interesting and they confirm the suggestion of the similarity of host reaction to pathogens taxonomically related. Nectria galligena and Pezicula malicorticis belong to the subdivision Ascomycotina, and Stereum purpureum belongs to Basidiomycotina. These three species belong to the group of higher fungi, whereas Phytophthora 'cactorum'differs from them considerably phyllogenetically and taxonomically. It may be supposed on the basis of the detected dependencies that collar rot is a disease with a different pathogenesis than bark canker, perennial canker and silver leaf.

From the practical point of view evaluation of the susceptibility of apple cultivars to the complex of bark canker fungi is important. As the result of such an attempted evaluation it is possible to distinguish five groups of cultivars with a different degree of susceptibility. Very susceptible cultivars: 'Delikates', 'Melrose', 'McIntosh', 'Spartan', 'Prima' and 'Slava Pobeditelam'. Rather susceptible cultivars: 'Starkrimson', 'Hibernal', 'Florina', 'Priscilla', 'Priam', 'Macfree' and the hybrid 'NY 55-158-2'. Moderately susceptible cultivars: 'Macoun', 'Liberty', 'NY 55-140-9', 'Vista Bella', 'Jerseymac' and 'Sampion'. Little susceptible cultivars: 'Golden Delicious', 'Idared' and 'NY 58-553-1'. None of the 26 apple cultivars tested was completely resistant to the fungi Nectria galligena, Pezicula malicorticis, Stereum purpureum and Phytophthora cactorum.

\section{REFERENCES}

A $1 \mathrm{~d}$ w i n c k l e H. S., L a m b R. C., 1974. Controlling apple diseases without chemicals. New York Food Life Science 10: 12-14.

A $1 \mathrm{~d} \mathrm{w}$ i n c k l e H. S., L a m b R. C., 1981. Use of host plant resistance in tree fruits. Proc. Int. Congr. Plant. Prot. 9th: 586-589.

B i e 1 e $n$ i n A., Borecki Z., 1970. Zgnilizna pierścieniowa podstawy pnia drzew owocowych powodowana przez grzyb Phytophthora cactorum. Acta Agrobot. 23: 253-266.

B o r e c k i Z., C z y n c z y k A., M i 11 i k a n D. F., 1978. Susceptibility of several cultivars of apple to bark canker fungi. Plant Dis. Rep. 62: 817-819.

B ore ck i Z., C z y n c z k A., P u c h a ła Z., M i 11 ik a n D. F., 1982. Resistance in apple to four canker fungi. Plant Dis. 66: 1027-1029.

B o r e c k i Z., P u c h a ł a Z., 1976. Zgorzel kory jabłoni wywoływana przez grzyby z rodzaju Pezicula. Rocz. Nauk Rol. E, 5: 55-72.

C a m e r o n H. R., 1977. Effect of viruses on deciduous fruit trees. Hortscience 12: 484-487.

D y e M. H., 1972. The silver leaf problem in fruit trees. Lecture given at a fruitgrowers seminar in Hastings on July 16, 1969. Schearer A. R. Gov. Printer, Wellington, New Zealand.

J e ffer s S. N., A l d w i n ck l e H.S., B u r r T.J., A r n e s o n P. A., 1982. Phytophthora and $P$ ythium species associated with crown rot in New York apple orchards. Phytopathology 72 : 533-538. 
K r a h m e r H., S c h m i d l e A., 1979. Uber đie Aunfalligkeit einiger neuer Apfelsorten für $N$. galligena Bres. und Phytophthora cactorum. Nachr. bl. Dt. Pflanz. sch. dienst 31: 89-92.

K r ü g e r Jutta, 1982. Susceptibility of apple varieties and hybrid progenies to canker $\langle$ Nectria galligena $>$ after artificial or natural infection. Abst. XXI Int. Hort. Connress, Hamburg p. 1015.

M a j z o u b G., 1978. Zur epiphytischen Besiedlung von Blatt-und Fruchtnarben bei Apfelbaumen und anderen Holzgewachsen durch pilzliche Fruchtfauleerreger, besonders Pezicula alba und $P$. malicorticis. Doktor Dissertation von dem Fachbereich Pflanzenproduktion der Universitat Hohenheim.

S i 1 b e r e i s e n R., 1978. Anbauwurdige neue Apfelsorten. Rhein. Monatschr. Gemuse, Obst. Schnittblumen 66: 138-140.

Wrażliwość odmian jabłoni na choroby powodowane przez grzyby pasożytnicze niszczące korę

\section{Streszczenie}

Badano wrażliwość 26 odmian jabłoni na cztery pasożyty kory: Nectria galligena, Pezicula malicorticis, Stereum purpureum i Phytophthora cactorum. Stwierdzono ścisłą korelację pomiędzy wskaźnikami wrażliwości na grzyby $N$. galligena, $P$. malicorticis i $S$. purpureum oraz brak korelacji pomiędzy wskaźnikami wraźliwości na $P$. cactorum i trzy pozostałe patogeny. Wyodrębniono pięć grup wrażliwości na kompleks patogenów kory, obejmujący trzy lub cztery gatunki grzybów. Odmiany bardzo wrażliwe: 'Delikates', 'Melrose', 'Spartan', 'Prima' i 'Słava Pobeditelam'. Odmiany dość wrażliwe: 'Starkrimson', 'Hibernal', 'Florina', 'Priscilla', 'Priam', 'Macfree' i 'NY 55-158-2'. Odmiany średnio wrażliwe: 'Macoun', 'Liberty', 'NY 55-140-9', 'Vista Bella', 'Jerseymac' i ‘Šampion'. Odmiany malo wrażkwe: 'Discovery', 'Empire', 'Fantazja' i 'Primula'. Odmiany bardzo mało wrażliwe: 'Golden Delicious', 'Idared' i 'NY 58-553-1'. 